\title{
The impact of selective logging on sympatric civet species in Borneo
}

\author{
Matthew J. Heydon and Pullin Bulloh
}

\begin{abstract}
Selective logging is the predominant method of commercial timber exploitation in South East Asia. Its effects upon mammalian carnivores have seldom been addressed, despite the vulnerability of these animals at the top of many food chains. The authors investigated the effects of logging by comparing the abundance of sympatric civet species, which display feeding strategies ranging from strict carnivory to frugivory, in primary and selectively logged rain forest in the Malaysian state of Sabah in northern Borneo. All species occurred in disturbed forest, but the overall density of civets in logged forest (6.4 individuals per sq $\mathrm{km}$ ) was found to be significantly lower than in primary forest (31.5 individuals per sq $\mathrm{km}$ ). This reflected a marked reduction in the abundance of civets from the predominantly carnivorous subfamilies Viverrinae and Hemigalinae.
\end{abstract}

\section{Introduction}

Civets form a highly diverse and prominent group of carnivores in the Old World tropics. On the island of Borneo alone, there are nine species (Payne et al., 1985), eight of which occur sympatrically in the Danum Valley Conservation Area, Sabah, Malaysia (ICSB, 1993). Although most civets are strictly nocturnal, other aspects of foraging behaviour have undergone considerable adaptive radiation (see Table 1). There are both terrestrial and arboreal species, and an otter-like aquatic form, Cynogale bennettii. In addition, despite their taxonomic status within the Carnivora, some civets feed extensively on fruit. Analysis of the stomach contents of three species revealed that, on average, fruit accounted for approximately 45 per cent of food bulk in Paradoxurus hermaphroditus, 12 per cent in Viverra tangalunga and 0 per cent in Hemigalus derbyanus (Davis, 1962). Fruits favoured by civets are generally sugar-rich and soft-pulped (Bartels, 1964; Rabinowitz, 1991; Heydon, unpubl. data). Arthropods and earthworms make up the bulk of animal matter eaten, at least in the species mentioned above.

Approximately 60 per cent of the land area (C) $1996 \mathrm{FFI}$ of the Malaysian state of Sabah was forested in 1990 (Marsh and Greer, 1992). Between 1975 and 1985 forest cover declined at a rate of 1.37 per cent per annum (FAO, 1987). Of the remaining forested areas, 64 per cent have been disturbed by human activity, predominantly through selective logging (Marsh and Greer, 1992).

In common with other forest-dwelling carnivores, little is known about the effects of selective logging on the diversity and density of civet populations. Studies investigating the influence of logging on vertebrates have generally focused on primates (e.g. Johns and Skorupa, 1987) or birds (e.g. Johns, 1986; Lambert, 1992; Thiollay, 1992). In part, this is due to the practical difficulties of studying carnivores in densely forested habitats.

Our aim was to test the hypothesis that selective logging has no effect on the density of civets in lowland rain forest.

\section{Study area}

The study was carried out between January 1992 and December 1993 within the Ulu Segama Forest Reserve in the Malaysian state 
Table 1. Sighting frequencies and overall density estimate for sympatric civet species in primary and selectively logged lowland rain forest in the Ulu Segama Forest Reserve, Sabah, Malaysia

\begin{tabular}{|c|c|c|c|c|c|c|}
\hline \multirow[b]{2}{*}{$\begin{array}{l}\text { Subfamily } \\
\text { Species }\end{array}$} & \multirow[b]{2}{*}{$\begin{array}{l}\text { Foraging } \\
\text { strategy* }\end{array}$} & \multirow[b]{2}{*}{ Diet $t$} & \multicolumn{2}{|c|}{ Primary forest $(\mathrm{PF})$} & \multicolumn{2}{|c|}{ Logged forest (LF) } \\
\hline & & & $N$ & $\begin{array}{l}\text { Sighting frequency } \S \\
(n / 100 \mathrm{~km} \text { trail })\end{array}$ & $N$ & $\begin{array}{l}\text { Sighting frequency§ } \\
(n / 100 \mathrm{~km} \text { trail })\end{array}$ \\
\hline \multicolumn{7}{|l|}{ Paradoxurinae (palm civets) } \\
\hline Paradoxurus hermaphroditus & $\mathrm{A} / \mathrm{T}$ & $\mathrm{F}$ & 5 & $11.1 \pm 4.4$ & 2 & $3.1 \pm 2.0$ \\
\hline Arctogalidia trivirgata & $\mathrm{A}$ & $\mathrm{F}$ & 1 & $2.1 \pm 2.1$ & 0 & $P$ \\
\hline Arctictis binturong & A & $\mathrm{F}$ & 1 & $1.7 \pm 1.7$ & 2 & $2.4 \pm 1.6$ \\
\hline Paguma larvata & $\mathrm{A} / \mathrm{T}$ & $\mathrm{I} ?$ & 0 & $\mathbf{P}$ & 0 & $\mathbf{P}$ \\
\hline \multicolumn{7}{|l|}{$\begin{array}{l}\text { Hemigalinae } \\
\text { (banded-palm civets) }\end{array}$} \\
\hline Hemigalus derbyanus & $\mathrm{T}$ & C & 11 & $19.5 \pm 9.1$ & 2 & $2.2 \pm 2.2 * *$ \\
\hline Cynogale bennettii & $\mathrm{T} / \mathrm{H}$ & C & 0 & $\mathrm{P}$ & 0 & $\mathrm{P}$ \\
\hline \multicolumn{7}{|l|}{$\begin{array}{l}\text { Viverrinae } \\
\text { (true civets and linsangs) }\end{array}$} \\
\hline Viverra tangalunga & $\mathrm{T}$ & I & 12 & $24.4 \pm 6.9$ & 5 & $6.1 \pm 2.1 * *$ \\
\hline Priondon linsang & $\mathrm{A} / \mathrm{T}$ & $\mathrm{C}$ & 2 & $4.1 \pm 2.4$ & 0 & $\mathrm{P}$ \\
\hline Total distance surveyed $(\mathrm{km})$ & & & 49.5 & & 72.3 & \\
\hline \multicolumn{5}{|c|}{ Total civet density $n / \mathrm{sq} \mathrm{km}$ (95\% confidence limits) 31.5 (19.9-49.9) } & \multicolumn{2}{|c|}{$6.4(3.2-13.1)^{* *}$} \\
\hline
\end{tabular}

* A, arboreal; $T$, terrestrial; $H$, aquatic.

† Estimated percentage of animal matter in diet: C, > 95\%; I, 95-60\%; F, <60\% (Davis, 1962; Payne et al., 1985). $\S$ Mean ( \pm SEM) for four transects in PF and six in LF.

$P$, not recorded during survey but seen between 1992 and 1993.

${ }^{* *} P<0.05$ for difference between PF and LF (Wilcoxon-Mann-Whitney test used for sighting frequencies and $z$-test for densities).

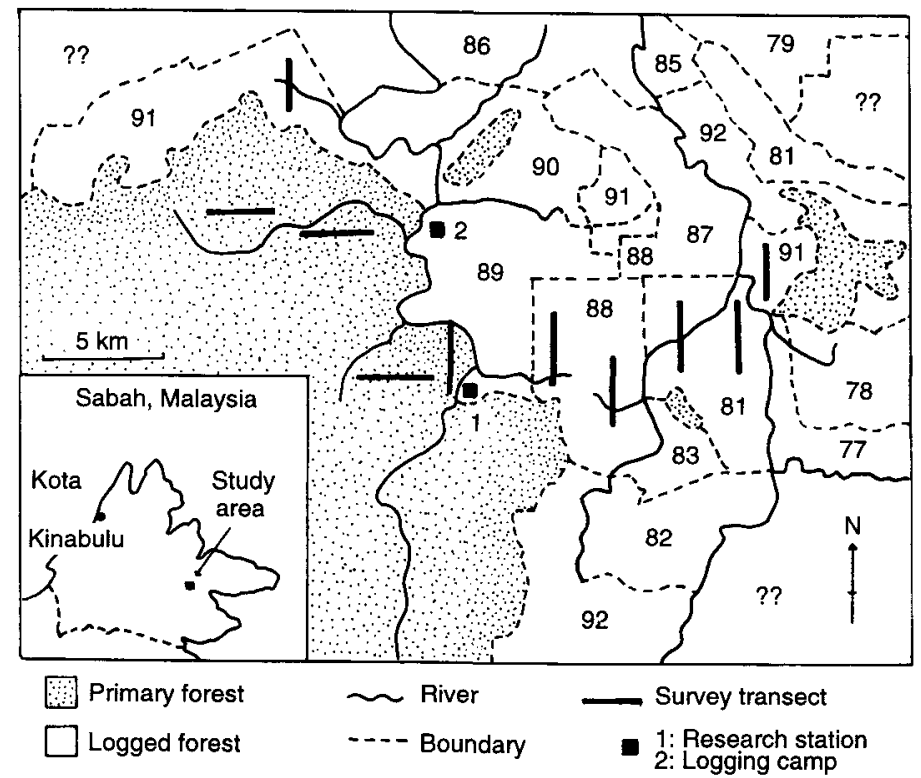

Figure 1. Map of study area showing locations of survey transects. Blocks of different-aged logged forest are distinguished by the year in which they were logged (e.g. $88=1988$, ?? = uncertain age). 
of Sabah $\left(4^{\circ} 58^{\prime} \mathrm{N}, 117^{\circ} 48^{\prime} \mathrm{E}\right.$, see Marsh and Greer, 1992). The reserve is dominated by lowland, evergreen dipterocarp forest (Newbery et al., 1992) and encompasses both selectively logged areas and primary forest (including the Danum Valley Conservation Area). Logging is monocyclic, in which all commercial stems are removed in the first cut and regeneration is effected from seedlings or the seed bank. The logging operation, using tracked vehicles and overhead cable systems, involves removal of approximately 7 per cent of large trees for commercial purposes (Johns, 1989). Damage levels (defined as percentage of trees greater than $30 \mathrm{~cm}$ girth destroyed) average 62 per cent using tractors and up to 80 per cent using overhead cables (Johns, 1989). Extraction rates of timber are typically high, averaging $118 \mathrm{cu}$ $\mathrm{m}$ per ha over the period 1970-90, with a range of 73-166 cu m per ha between different logged areas (Marsh and Greer, 1992).

Human settlement in the study area is limited to a logging camp and a research station, both established since 1985 (see Figure 1). Historically, human presence in the area appears to have been limited to sporadic use of riverine fringes for shifting cultivation of rice paddy, with no clear evidence for this occurring during the twentieth century. Hunting is prohibited within the reserve and little, if any, poaching is believed to occur. This enabled the present study to examine the direct consequences of logging without the added complications associated with increased hunting pressure accompanying improved access following logging.

\section{Methodology}

Records were kept of all civets observed within the Ulu Segama Forest Reserve during 1992 and 1993. Additionally, the density of civets was estimated by nocturnal line transect surveys. Ten transects following either a north-south or east-west compass bearing were used. Transect paths were approximately $1 \mathrm{~m}$ wide and between 2 and $3 \mathrm{~km}$ long. This design was adopted to ensure that the mosaic of vegetation types that make up selectively logged forest (including patches of undisturbed forest) were sampled in proportion to their abundance. Four of the trails were in primary forest $(\mathrm{PF})$, and two each were in forest logged 2, 5 and 12 years previously (LF, see Figure 1). Details of the vegetation composition of primary and logged forest areas have been described in Heydon (1994). Surveys were carried out on foot by two observers using spotlights with a $5.3 \mathrm{~V}, 1 \mathrm{~A}$ halogen bulb. Each survey started at $19.00 \mathrm{~h}$ (1 hour after dusk) with observers travelling at 500-700 $\mathrm{m}$ per $\mathrm{h}$. The perpendicular distance from the transect line of each civet observed was measured with a tape measure. Transects were surveyed once a month over a 5-month period between August and December 1993. Densities were determined using the DISTANCE program (Laake et al., 1993).

\section{Results}

Observations between 1992 and 1993 confirmed that all eight species of civet identified in the virgin forested Danum Valley Conservation Area were also present in the surrounding logged forest, including the rare otter civet Cynogale bennettii (Table 1). During the transect surveys, 32 individuals from six of these species were sighted in primary forest, whereas only 12 individuals from four species were recorded in logged forest, despite a greater sampling effort (Table 1).

There were insufficient sightings to estimate the densities of individual species of civet using line transect methodology (Buckland $e t$ al., 1993). Instead, we have pooled the data to produce an estimate of the total density of all civets for each forest type. This required two assumptions: that the probability of sighting civets in primary and logged forest at similar distances from the transect line was comparable, and that the different species were seen with equal probability. In both cases it is predicted that sighting probabilities will be most affected by the density of vegetation and the height at which the civets foraged. Differences in body colour and size (head-body-length range 38-79 cm; Payne et al., 1985) had little 
consequence when locating individuals by their eye-shine. Despite differences in forest structure there were, however, no statistically significant differences $(z$-test, $p>0.05)$ in the effective strip-width of sampling when data were stratified by forest type ( $\mathrm{PF}=9.8 \pm 1.6 \mathrm{~m}$; $\mathrm{LF}=9.1 \pm 2.4 \mathrm{~m})$ or height at which individuals foraged (terrestrial $=8.3 \pm 1.5 \mathrm{~m}$; arboreal $=11.2 \pm 3.8 \mathrm{~m}$ ). There were also no differences in the average sighting distances of civets from transect paths (Kruskal-Wallis test, forest type: $\mathrm{K}-\mathrm{W}=0.12, \mathrm{df}=1, P=0.73$; foraging height: $\mathrm{K}-\mathrm{W}=2.03, \mathrm{df}=1, P=0.15$ ).

We believe that the density estimates obtained (Table 1) provide a reasonable comparison of the two forest types and that the substantially lower density of civets in logged forest is a genuine difference. The variation between the forest types mainly reflects the markedly lower sighting frequencies of Malay civet Viverra tangalunga and especially the banded palm civet Hemigalus derbyanus in logged forest. The data suggest that the predominantly carnivorous species of civet (subfamilies Hemigalinae and Viverrinae) were more adversely affected by logging than the more omnivorous civets (subfamily Paradoxurinae). Sighting frequencies of the former in logged forest were only one-sixth of frequencies in primary forest, whereas for Paradoxurinae, the value was one-third.

\section{Conclusions}

There have been few attempts to investigate the effects of selective logging upon mammalian carnivores. Unpublished data collected by A.D. Grieser Johns from the same forest also found lower sighting frequencies of civets in logged forest, but not a marked difference between the carnivorous and omnivorous subfamilies (Table 2). Variation between the present study and these data may reflect methodological differences; the transect paths used by Grieser Johns often followed logging roads, rather than a compass bearing (Johns, 1989). The forest along old roads is a distinct micro-habitat within the mosaic of vegetation types that comprise logged forest. The use of

Table 2. Sighting frequencies for sympatric civet species in primary and 6-year-old selectively logged lowland rain forest in the Ulu Segama Forest Reserve

\begin{tabular}{|c|c|c|c|c|}
\hline \multirow[b]{2}{*}{$\begin{array}{l}\text { Subfamily } \\
\text { Species }\end{array}$} & \multicolumn{2}{|c|}{ Primary forest* } & \multicolumn{2}{|c|}{ 6-year-old logged forest* } \\
\hline & $N$ & $\begin{array}{l}\text { Sighting frequency } \\
(n / 100 \mathrm{~km} \text { trail })\end{array}$ & $N$ & $\begin{array}{l}\text { Sighting frequency } \\
(n / 100 \mathrm{~km} \text { trail) }\end{array}$ \\
\hline \multicolumn{5}{|l|}{ Paradoxurinae (palm civets) } \\
\hline Paradoxurus hermaphroditus & 4 & 8.3 & 0 & 0 \\
\hline Arctogalidia trivirgata & 3 & 6.2 & 2 & 8.8 \\
\hline Arctictis binturong & 0 & $\mathbf{P}$ & 0 & 0 \\
\hline Paguma larvata & 0 & 0 & 0 & 0 \\
\hline \multicolumn{5}{|c|}{ Hemigalinae (banded-palm civets) } \\
\hline Hernigalus derbyanus & 1 & 2.1 & 1 & 4.4 \\
\hline Cynogale bennettii & 1 & 2.1 & 0 & 0 \\
\hline \multicolumn{5}{|c|}{ Viverrinae (true civets and linsangs) } \\
\hline Viverra tangalunga & 8 & 16.6 & 2 & 8.8 \\
\hline Priondon linsang & 1 & 2.1 & 0 & 0 \\
\hline Total distance surveyed $(\mathrm{km})$ & & 48 & & 23 \\
\hline
\end{tabular}

* Data from two sites combined. Logged forest transects often followed old logging roads.

$P$, present but not seen during surveys.

Source: A. D. Grieser Johns, unpublished data (collected 1987-88). 
straight-line transects in this study should provide a more representative assessment of the abundance of civets in such a heterogeneous environment.

Evidence that dietary generalists fair better after logging than taxa with more restricted feeding habits has also been reported in primates and ungulates within the Ulu Segama Forest Reserve (Johns, 1992; Heydon, 1994). Species dependent on invertebrates appear to be particularly vulnerable. Lambert (1992) reported that most of the rare bird species in logged forest were insectivores. Among primates, densities of the predominately insectivorous and entirely carnivorous western tarsier Tarsius bancanus showed a decline of approximately 50 per cent (Heydon, 1994). Similarly, our data on civets suggest that the more carnivorous species, again mainly feeding on invertebrates (Davis, 1962), are proportionately scarcer in logged forest. While these observations imply that logging has an adverse effect on the availability of invertebrates, data from studies investigating this issue are ambiguous. Burghouts et al. (1992) found that the overall numerical abundance of litter invertebrates was lower in logged forest than primary forest in the Ulu Segama. Nevertheless, of the invertebrates known to be eaten by civets (Davis, 1962; M. J. Heydon, unpubl. data) only Scorpionidae and Isoptera are reported to be significantly more abundant in primary forest while Coleoptera and Hymenoptera are more common in logged forest (Burghouts et al., 1992; Korthals, 1990). To resolve this issue, information is needed on the dietary importance of different invertebrates, as well as other factors affecting their significance as a food resource (e.g. temporal availability and biomass).

Timber extraction rates in Sabah are among the highest in the world (Sundberg, 1983), which undoubtedly contributes to the high levels of forest disturbance during logging (Johns, 1989). Thus, it may be appropriate to view the effects of selective logging on animal populations in the Ulu Segama as representing a 'worst-case scenario' (Lambert, 1992). With this in mind, the presence of all civet species in logged forest is promising. Similar high levels of survival have also been reported for primates, ungulates and birds in the Ulu Segama (Heydon, 1994; Johns, 1992; Lambert, 1992). This should not encourage a complacent attitude towards conservation. Overall, the density of civets was dramatically reduced by logging and it is uncertain what long-term effects this might have on breeding success of individual species. Depressed breeding rates have been reported in primate species 6 years after less intensive logging in Tekam, peninsular Malaysia (Johns, 1992). The effects on breeding rates in civets could not be assessed because juveniles are seldom observed, even in primary forest.

Because the specific causes of the decline in civet abundance were not identified, the best conservation strategy that can be recommended is to reduce the level of forest disturbance caused by timber harvesting, in particular damage to non-commercial trees. To achieve this, radical changes are necessary in the methods used to harvest timber. The impetus may be provided by carbon sequestration initiatives (see Marsh, 1993). The Sabah Foundation (Yayasan Sabah), which manages the Ulu Segama Forest Reserve, is undertaking a pilot programme aimed at developing improved forestry practices for use in future logging operations (Putz and Pinard, 1993). If successful, it is envisaged that disturbance to the forest will be reduced by approximately 50 per cent (Putz and Pinard, 1993). At a site in west Malaysia, where timber extraction levels are significantly lower than in Sabah (typically $50 \mathrm{cu} \mathrm{m}$ per ha; Johns, 1988) sighting frequencies of some civets increased after logging (A.D. Grieser Johns, unpubl. data). This suggests that, with reduced disturbance during logging, civet densities may not be as adversely affected. It is vital that further research is carried out to assess the consequences of these 'improved' logging techniques for civet and other vertebrate populations.

\section{Acknowledgements}

M.J.H. is grateful to the Economic Planning Unit of the Malaysian Federal Government, the Danum Valley Management Committee and Jabatan Hidupan Liar (the Sabah Wildlife Department) for 
permission to conduct research in Malaysia. We are indebted to the Director of Jabatan Hidupan Liar, Mahedi Andau, and his staff for advice and support. We also thank the Sabah Foundation for support, with particular thanks to Tengku D. Z. Adlin, Clive Marsh, Jikos Gidiman, Isabello Garcia and the staff of the Danum Valley Field Centre. Advice and practical assistance were provided by Nilofer Ghaffar and Palin Bulloh. The project was funded by grants to Adrian Marshall from the Royal Society (UK) and under ODA/NERC contract F3CR26/G1/05 for studies on the effects of disturbance upon vertebrate populations in South East Asia. We are grateful for the comments of two anonymous referees and to Andrew Grieser Johns who permitted us to quote his unpublished data. This paper is Number A/108 of the Royal Society's South East Asian Rain Forest Research Programme.

\section{References}

Bartels, E. 1964. On Paradoxus hermaphroditus javanicus (Horsfield, 1824). The common palm civet or tody cat in Western Java. Notes on its food and feeding habits. Its ecological importance for wood and rural biotopes. Beaufortia, 10 (124), 193-201.

Buckland, S.T., Anderson, D.R., Burnham, K.P. and Laake, J.L. 1993. Distance Sampling: Estimating Abundance of Biological Populations. Chapman and Hall, London.

Burghouts, T., Ernsting, G., Korthals, G. and De Vries, T. 1992. Litterfall, leaf litter decomposition and litter invertebrates in primary and selectively logged dipterocarp forest in Sabah, Malaysia. Phil. Trans. R. Soc. Lond. B 335, 407-416.

Davis, D.D. 1962. Mammals of the lowland rain forest of North Borneo. Bull. Nat. Mus., Singapore, 31, 1-129.

FAO. 1987. Development of Forest Sector Planning, Malaysia: Inventory. FO: DP/MAL/85/004 Technical Report no. 1. FAO, Rome.

Heydon, M.J. 1994. The Ecology and Management of Rain-Forest Ungulates in Sabah, Malaysia: Implications of Forest Disturbance. Unpublished report, Institute of Tropical Biology, University of Aberdeen.

Innoprise Corporation Sdn. Bhd. 1993. Danum Valley Conservation Area: A Checklist of Vertebrates. Innoprise Corporation Sdn. Bhd., Kota Kinabalu.

Johns, A.D. 1986. Effects of selective logging on the ecological organization of a peninsular Malaysian rain forest avifauna. Forktail, 1, 65-79.

Johns, A.D. 1988. Effects of 'selective' timber extraction on rainforest structure and composition and some consequences for frugivores and folivores. Biotropica, 20, 31-37.

Johns, A.D. 1989. Timber, the Environment and Wildlife in Malaysian Rain Forest. Unpublished re- port, Institute of Tropical Biology, University of Aberdeen.

Johns, A.D. 1992. Vertebrate responses to selective logging: implications for the design of logging systems. Phil. Trans. R. Soc. Lond. B 335, 437-442.

Johns, A.D. and Skorupa, J.P. 1987. Responses of rain-forest primates to habitat disturbance: a review. Int. J. Primatol. 6 (2), 157-191.

Korthals, G.W. 1990. A Description of the LitterDwelling Arthropod Fauna in a Primary and Secondary Rain Forest in North-east Borneo. Unpublished report. Free University, Amsterdam.

Laake, J.L., Buckland, S.T., Anderson, D.R. and Burnham, K.P. 1993. Distance Users Guide Ver. 2.0. Colorado Cooperative Fish and Wildlife Research Unit, Colorado State University, Fort Collins, CO.

Lambert, F.R. 1992. The consequences of selective logging for Bornean lowland forest birds. Phil. Trans. R. Soc. Lond. B 335, 443-457.

Marsh, C.W. 1993. Carbon dioxide offsets as potential funding for improved tropical forest management. Oryx, 27, 2-3.

Marsh, C.W. and Greer, A.G. 1992. Forest land-use in Sabah, Malaysia: an introduction to Danum Valley. Phil. Trans. R. Soc. Lond. B 335, 331-339.

Newbery, D.McC., Campbell, E.L.F., Lee, Y.F., Ridsdale, C.E.H. and Still, M.J. 1992. Primary lowland dipterocarp forest at Danum Valley, Sabah, Malaysia: structure, relative abundance and family composition. Phil. Trans. R. Soc. Lond. B335, 341-356.

Payne, J., Francis, C.M. and Phillipps, K. 1985. A Field Guide to the Mammals of Borneo. The Sabah Society and WWF, Kuala Lumpar.

Putz, F.E. and Pinard, M. 1993. Reduced impact logging as a carbon offset method. Conserv. Biol. 7, 755-757.

Rabinowitz, A.R. 1991. Behaviour and movements of sympatric civet species in Huai Kha Khaeng Wildlife Sanctuary, Thailand. J. Zool., Lond. 223, 281-298.

Sundberg, U. 1983. Logging in Broadleaved Tropical Forests. FO:RAS/78/010 Working Paper no. 27. FAO, Rome.

Thiollay, J.-M. 1992. Influence of selective logging on bird species diversity in a Guianan rain forest. Conserv. Biol. 6, 47-63.

Matthew J. Heydon, Institute of Tropical Biology, Department of Zoology, University of Aberdeen, Aberdeen AB9 2TN, UK. Present address: The Game Conservancy Trust, Fordingbridge, Hampshire SP6 1EF, UK.

Pullin Bulloh, c/o Pejabet Pengingpin Kemajuan Rakyat, No. 19, Tingkat Dua Bangunan, Urusatia Kecil, 91100 Lahad Datu, Sabah, Malaysia.

(C) $1996 \mathrm{FFI}$, Oryx, $30(1), 31-36$ 